\title{
Explainer:
}

\section{Taxing rezoning windfalls (betterment)}

\author{
May 2021
}

\author{
Dr Cameron K. Murray \\ Henry Halloran Trust, The University of Sydney
}

In its 2021 budget, the Victorian government announced a new tax on windfall land value gains from rezoning (also known as a betterment tax)

This note explains the economic principles behind such a tax, the benefits of applying such a tax, implementation issues that need to be considered, and lessons from the operation of similar taxes elsewhere.

Property is, conceptually, a finite bundle of rights. Rezoning grants additional property rights to owners of an existing set of property rights. Those new rights could instead be sold at a market price. A tax on the value gain from rezoning at anything less than $100 \%$ is equivalent to selling the new property rights from the community to the current property owner at a discount. Just like selling other property rights from the public to the private sector does not add to market prices in property markets, nor does selling rezoning rights.

A tax on rezoning windfalls is uncommon not because it is a bad tax but because it is a good tax.

\section{What is the source of rezoning gains?}

The answer to this question relies on understanding the nature and extent of property rights. A core right of a property owner is to exclude others. A right holder of this type usually also has a residual claim to income generated in the space over which they have exclusionary rights ("pay to use this space or l'll exclude you from it").

But these rights are limited. They evolve as the law evolves, including zoning and planning law. Rights to access and sell minerals within a property's exclusive space, for example, are not part of the private property rights bundle in Australia. They are instead owned collectively by States.

The value of private property rights is primarily determined by how much revenue can be generated above costs (excluding property rights costs) on a site at a particular location. The value of property rights is a residual, just as other assets like shares in company ownership represent residual claims on income. Whichever use of a site generates the largest residual income is its highest value use.

The revenue potential of private property rights is affected by market conditions, locationspecific features, fixed improvements, and the nature and extent of the property rights bundle itself. Investing in new fixed improvements, like buildings and earthworks, can add to property value because they remove a cost to gaining revenue (remember, property value is revenue minus costs needed to earn that revenue at that location). The value of fixed improvements 
becomes "attached" to the property as they cannot be separated physically or legally from the property right to a location.

However, the value of private property rights can also increase due to external factors that are not due to investments made by the property rights owner. When this occurs, it is known as betterment. For example, new public works that improve the accessibility of a location will increase the value of those sites because they reduce the transport costs of using those sites to generate revenue. Similarly, when the law changes the nature or extent of property rights in a way that increases the revenue-generating potential of that site, such as with rezoning, the resulting increase in value of the property rights bundle is betterment.

Planning rules coordinate property uses across locations by defining property rights bundles. For this coordination role to affect property uses it must legally restrict some uses so that the highest value legal use is different to what might occur with a "no zoning" property rights bundle. Hence, there is an inherent conflict between maximising the value of any individual property and coordinating the location of property uses across a region.

The diagram in Figure 1 shows how betterment arises conceptually and how a tax on betterment transfers value to the public that would otherwise accrue to private property owners.

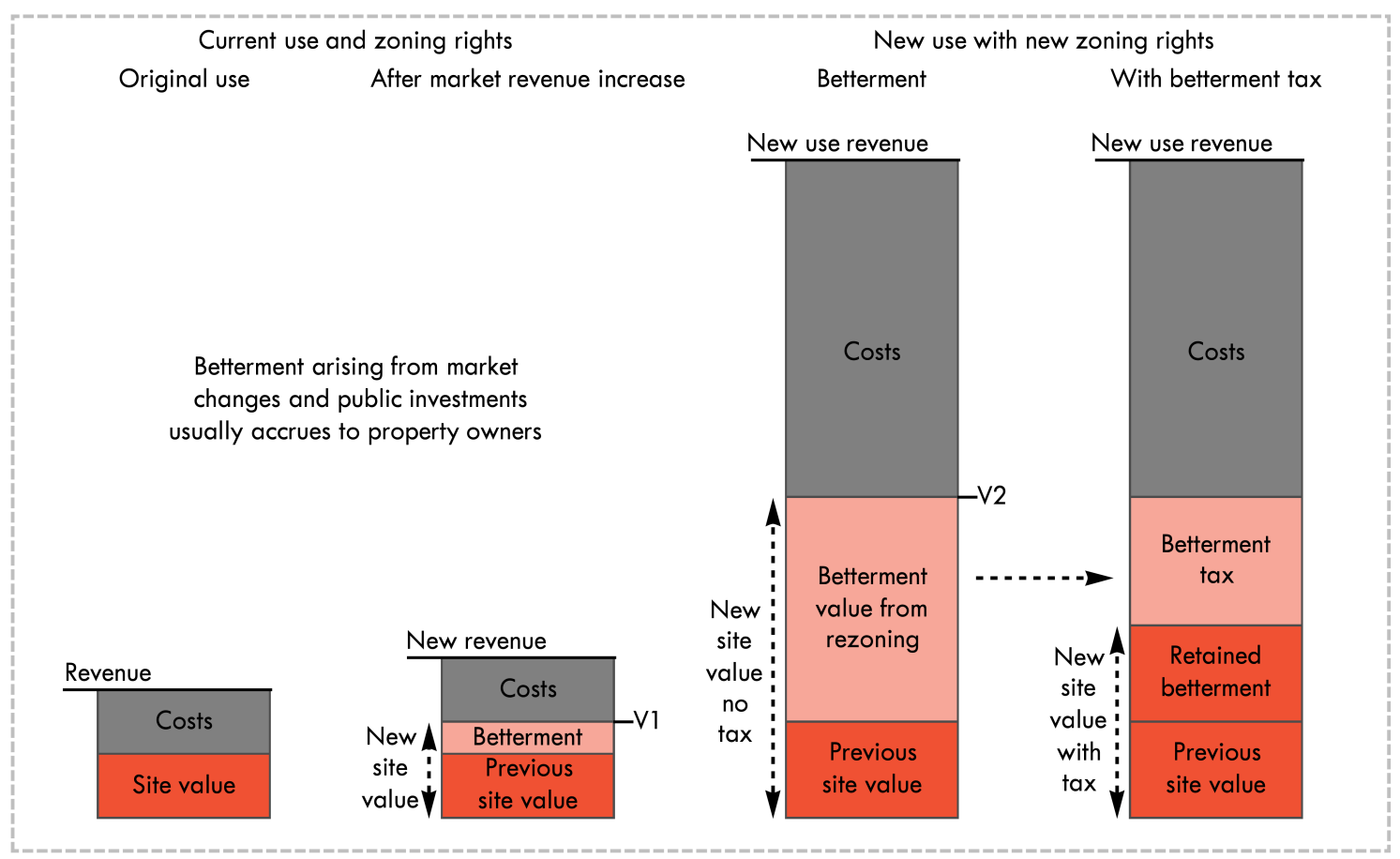

Figure 1: Betterment in the residual model of property value

The left column shows the value of the property rights at a site, such as agricultural or industrial land. That value is determined by the revenue that can be made from exclusively using that site, minus the necessary costs. The site's property rights value is the residual.

Suppose the market value of the output being produced increases, such as the value of crops on an agricultural property, but all input costs remain the same. In that case, the site value rises to reflect the higher residual value of production on that site. The new site value and its betterment component from these external factors is shown in the second column of Figure 1. Another example is if the rent of a residential dwelling rises, but the costs of operating that dwelling remain constant. This increases the property value. Where a property tax system exists, some of the value gains accruing to property rights from higher market prices of production are shared with the public.

The third column of Figure 1 shows what happens if there is a change in the nature or extent of the property rights through rezoning. For example, if the previous highest value use of a site was industrial only because zoning laws prevented other higher value uses such as residential, 
then rezoning will change the highest value legal use of the site and hence its value. The difference between the "before" site value (V1) and the new "after" site value (V2) is betterment.

A flexible planning system presents opportunities to increase revenue from development by exceeding codified density limits and hence offers another way to generate betterment for a landowner. The betterment gained from exceeding codified planning density limits is just as real as the betterment gained from rezoning. It is why, despite cost, risk, and time involved, many property owners seek planning dispensation instead of complying with codes and gaining fast approvals.

Here is a useful way to conceptualist betterment. Rezoning adds an additional private property right to the previously owned bundle. The value of this new right is betterment, and it reflects what the market would pay if these new property rights were instead auctioned for sale to existing property owners.

The effect of a tax on betterment arising from rezoning is illustrated in the fourth column of Figure 1 using the $50 \%$ tax rate proposed in Victoria. A share of the betterment value is transferred from the private property owner to the public, reducing the private payoff from rezoning decisions and increasing the public's share.

The size of betterment from rezoning can be extraordinarily large, often many multiples of the previous site value. For example, a well-situated industrial site in Sydney's inner west was bought for $\$ 8.5$ million, rezoned high-density residential, then sold again just a few years later for $\$ 48.5$ million. ${ }^{1}$

Rezoning at Fishermans Bend in Melbourne led to numerous sites trading at values many multiples of their previous industrial use values. At 320 Plummer Street, Port Melbourne, the $7,468 \mathrm{~m} 2$ site formerly used as the Rootes (Chrysler) factory transacted in 2009 for $\$ 1.7$ million with industrial zoning rights. After rezoning to high-density residential, an application was made and approved for the development of three towers containing 443 dwellings and $908 \mathrm{~m} 2$ of commercial floor area. The property was subsequently purchased for over $\$ 11$ million. Even after inflating the 2009 sale price to $\$ 3$ million to reflect sale prices in 2015 for similar industrial properties, the windfall rezoning betterment is roughly $\$ 8$ million, with the site trading for nearly four times its previous value. ${ }^{2}$

Notably, betterment is not an additional cost to housing development. The value of property rights is a residual; after all, there are no input costs to these rights. Betterment merely reflects the change in the market value of the residual claim on income of the property rights owner, and taxing betterment merely transfers this value from the property rights owner to the community.

\section{Community benefits}

There are numerous economic benefits from a rezoning betterment tax.

Regarding its economic effects, a betterment tax is on the net value gain; any existing charges on development are treated as any other development cost and subtracted from revenue to determine the site value. There is no "double taxation". If infrastructure contributions rise, then betterment will automatically fall, and vice-versa.

\footnotetext{
1 Chancellor, J. 201 2. Harry Triguboff's Meriton buys Lewisham Estates development site for $\$ 48.5$ million urban.com.au Available at https://www.urban.com.au/expert-insights/investing/17465unsubbed-triguboff
}

2 Sims, E. and Hermans, J. (Forthcoming) The Rezoning Honeypot: Evidence from Fishermans Bend Prosper Australia Research Institute. 
A betterment tax also retains the ordering of the value of different uses. If developing to a higher value use after rezoning is profitable without a betterment tax, it is also profitable with one.

Conceptually, the value of the property rights that are privatised via rezoning are economically equivalent to government budget spending. This can be seen by considering the alternative scenario where the value of these publicly held property rights is fully captured as public revenue when given to private property owners. Therefore, taxing rezoning betterment will reduce required tax contributions elsewhere.

A major benefit is that it reduces costs for compulsory public acquisition of private property for the purposes of public infrastructure. When the public retains the value of development rights, they do not have to buy them back. For example, an industrial site in Altona North in Melbourne was bought by a developer for $\$ 8.7$ million, rezoned for "comprehensive development" and then compulsorily acquired by the Victorian government for the West Gate Tunnel project for $\$ 22.5$ million. ${ }^{3}$ With a rezoning betterment tax in place, that site could have been acquired for millions less.

Finally, a rezoning betterment tax reduces the private payoff from corrupt dealings and political favouritism in the planning system. ${ }^{4}$ It acts as a type of insurance policy against corruption, ensuring that a substantial part of any betterment created is shared with the public rather than ending up in the hands of political mates.

\section{Policy design considerations}

Because it is a cost to realise a revenue like any other cost, a rezoning betterment tax will reduce the price at which rezoned property will transact prior to the tax being paid. This is important for two key policy design decisions:

1. The trigger that determines when the tax liability is paid, and

2. The "before" (V1) and "after" (V2) values, where the difference between these two values determines the betterment tax base. ${ }^{5}$

Typically, a rezoning betterment tax is triggered in either of two ways: First, on the sale of a property. Second, at the time of planning approval to vary the use of the site to take advantage of the additional property rights from higher value zoning. The choice of trigger for a betterment tax has important implications for how the "before" and "after" market values are assessed to determine the tax base.

\section{Trigger on sale}

If a property sale triggers a betterment tax, the first implementation issue is who pays the tax; the buyer (like stamp duty) or the seller. If the buyer pays, they will subtract this tax liability from the price they are willing to offer the seller. This means that the market price after rezoning will be lower because of the existence of the tax. If the tax is applied on a tax base

\footnotetext{
3 Murray, C.K. 2020. Our states are crying poor. They wouldn't if they charged for rezoning. The Conversation. 4 August. Available at https://theconversation.com/our-states-are-crying-poor-they= wouldnt-if-they-charged-for-rezoning-142838

${ }^{4}$ Murray, C.K. and P. Frijters. 2017. Game of Mates: How favours bleed the nation. Brisbane: Publicious. Available at https://gameofmates.com

${ }^{5}$ Where $\mathrm{V} 2-\mathrm{V} 1=$ tax base.
} 
where the "after" (V2) value is the exchange value for rezoned sites that retain a tax liability, then the tax base is significantly reduced. ${ }^{6}$

If the seller pays, this issue is avoided, as the buyer is paying a market price for the property that reflects the new zoning but with no rezoning windfall tax liability. The market price (V2) will be the same in this case regardless of whether the tax exists or not, and it is therefore a preferable approach. However, rigorous monitoring and enforcement to limit side payments between buyers and sellers to reduce market contract prices (and hence tax liabilities) will be needed.

There are two other implementation issues from using a sales trigger. First, planning systems in Australian jurisdictions are flexible, and zoning codes are not hard limits on density or use.

Second, property values change over time, and multiple sales can occur over a period of time where there are multiple zoning changes.

Because of planning system flexibility, a sale may trigger a windfall rezoning tax to be paid based on codified zoning rules. However, the new buyer may choose to make a planning application that greatly exceeds codified limits on density or use and be approved for this even higher value use. Unless there is another tax trigger, this additional betterment value will accrue to the property owner.

Because market values and zoning change over time, dealing with multiple rezoning and sales of the same property will be needed in a system with a sale trigger. This means determining what type of zoning changes have a rezoning tax liability, keeping a database record of these zoning changes with records of sales, assessed values and rezoning windfall taxes paid. This complexity opens up many potential points of conflict and additional administration costs and makes valuation comparisons with other sales more difficult as each market sale may have different historical rezoning tax payments associated with it that affect the current sale value.

Finally, a trigger on sale reduces the tax earned in a rising property market. If a sale occurs today and a rezoning tax liability is paid reflecting today's market values, but then the property is developed to that higher value use in ten years' time, the potentially significant value gain over that ten-year period, perhaps as a result of local public investments, remains with the property owner.

\section{Trigger on development approval}

The second trigger for a rezoning betterment tax is on a development approval. This has numerous advantages over the sale trigger.

First, in establishing the "after" (V2) value to determine the betterment tax base, the value of the actual approved scale and type of development is the benchmark, regardless of the codified zoning controls. If the approval exceeds the density and use limits, the tax also captures a part of that additional betterment.

Second, the comparison with market sales prices is more straightforward, as sales of property with development approvals all have no further tax liabilities. In the case of multiple development approvals prior to development, the same "before" (V1) value can be used as the benchmark, with new "after" (V2) values determined on the basis of the scope of each approval. Any previous rezoning windfall taxes paid can be subtracted to ensure that additional betterment is taxed on a net basis.

Table 1 shows how this trigger and the "before" (V1) and "after" (V2) assessments would apply to the previous Fishermans Bend example where multiple development approvals (DAs) occur prior to development taking place. The "before" (V1) value is based on comparable sales assuming the site's current use is its highest value use. This would be $\$ 3$ million based on

\footnotetext{
${ }^{6}$ The market price with a betterment tax in this scenario will be the pre-rezoning price plus the full betterment divided by one plus the tax rate (after rezoning price $=$ before rezoning price + total betterment / [1 + tax rate $]$ ).
} 
comparable industrial sales. However, this is not the price the site would trade for with the current zoning. Because the property owner retains part of the betterment even with a rezoning betterment tax, the property with higher value zoning rights will trade for a value above its current use value. In Table 1 this is shown in the second column, where the $\$ 7 \mathrm{~m}$ represents the new use value minus the expected rezoning betterment tax. ${ }^{7}$ Therefore, the "before" (VI) value benchmark will often need to ignore the property's own sale price and be derived from sales evidence.

The "after" (V2) value is the value the site would trade at with that particular development approval (where there is no rezoning betterment liability). The tax base is $\mathrm{V} 2-\mathrm{V} 1$, in this case $\$ 8$ million, and with a $50 \%$ tax rate that would imply a $\$ 4$ million tax liability at the time of the development approval.

Table 1: The effect of a 50\% rezoning betterment tax for an example site with multiple DAs

\begin{tabular}{cccccc}
\hline & $\begin{array}{c}\text { Before } \\
\text { rezoning } \\
\text { value } \\
\text { (V1) }\end{array}$ & $\begin{array}{c}\text { After rezoning } \\
\text { but before } \\
\text { development } \\
\text { application }\end{array}$ & $\begin{array}{c}\text { After rezoning, } \\
\text { development } \\
\text { application and } \\
\text { tax paid (V2) }\end{array}$ & $\begin{array}{c}\text { Betterment tax } \\
\text { base }\end{array}$ & $\begin{array}{c}\text { Net } \\
\text { betterment } \\
\text { tax raised }\end{array}$ \\
\hline $\begin{array}{c}\text { First } \\
\text { DA }\end{array}$ & $\$ 3 \mathrm{~m}$ & $\$ 7 \mathrm{~m}$ & $\$ 11 \mathrm{~m}$ & $\mathrm{~V} 2-\mathrm{V} 1=$ & $\$ 4 \mathrm{~m}$ \\
$\$ 8 \mathrm{~m}$ & \\
\hline $\begin{array}{c}\text { Second } \\
\text { DA }\end{array}$ & $\$ 3 \mathrm{~m}$ & $\$ 7 \mathrm{~m}$ & $\$ 15 \mathrm{~m}$ & $\begin{array}{c}\mathrm{V}-\mathrm{V} 1= \\
\$ 12 \mathrm{~m}\end{array}$ & $\begin{array}{r}\$ 6 \mathrm{~m}-\$ 4 \mathrm{~m} \\
=\$ 2 \mathrm{~m}\end{array}$ \\
\hline
\end{tabular}

If a second development approval is granted before any development takes place, the same assessment occurs (shown in the final row of Table 1). In this hypothetical scenario, the subsequent approval is for even more density, and hence the value of a site with this new second approval is \$15 million. The "after" (V2) value for this tax assessment is \$15 million, the "before" (V1) value is the same benchmark current use value, and the tax base is the $\$ 12$ million difference, creating a $\$ 6$ million liability at a $50 \%$ tax rate. However, because this site has previously paid a $\$ 4$ million rezoning betterment tax, this amount is subtracted to result in a betterment tax liability for this second approval of $\$ 2$ million.

The benefit of using the development approval trigger is that, although it taxes betterment arising from rezoning, it is blind to the actual content of zoning laws. The two benchmark values for determining the tax base are simply the value assuming the current use is the highest value use, and the value of the approved use. No monitoring of zoning controls is required, only records of previous rezoning betterment taxes.

\section{Lessons from existing taxes}

In the late 1960s there was political pressure to regain a public share of the value of government-granted development rights. This resulted in taxes on rezoning betterment being enacted in Sydney, Canberra, and numerous cities globally over the following decade.

\footnotetext{
7 Valuation guidance for the application of the planning approval trigger in ACT's rezoning tax expressly notes the likelihood that trades of a site currently with a low value use but in a higher value use zone will sell at a premium even where a rezoning betterment tax exists. https://www.revenue.act.gov.au/lvc/lvc-valuation-guidelines
} 
In Sydney from 1970-74 a 30\% rezoning betterment tax applied for the conversion of land from rural to urban uses. The tax payment was triggered by a sale or development approval. It raised $\$ 17$ million over its 4.5 years of operation. ${ }^{8}$

The ACT has had a betterment tax in some form since 1971. Its current incarnation is the Lease Variation Charge (LVC), which is payable upon an approved development application (though payment timing can be deferred for a period). In 2018-19 it raised $\$ 53$ million in revenue and $\$ 27$ million in 2019-20.9 Recently, the ACT system codified the tax payable on a precinct-by-precinct basis for single use developments based on pre-calculated assessments of a $75 \%$ of value gain for different use types. ${ }^{10}$ Over its 40 -year operation there have been many implementation improvements and simplifications that can inform new rezoning taxes elsewhere. ${ }^{11}$

One way that the ACT captures rezoning betterment for the community is by deploying a public agency to undertake all greenfield land development. This means that the public captures $100 \%$ of the betterment from converting rural to urban uses. In 2019-20, $\$ 100$ million of net revenue for the government was raised from this approach, representing the betterment value from rural to urban land conversion. ${ }^{12}$

Numerous cities implement variations of this "public purchase, rezone and develop" approach. Public agencies acquire major un- and under-developed sites prior to rezoning and masterplanning for urban uses, then sell most of the up-zoned properties with new roads and infrastructure for private development. ${ }^{13}$ This not only captures for the public $100 \%$ of the betterment, but also allows greater coordination of public infrastructure investment without acquiring private property with high value zoning rights.

São Paulo, Brazil has for decades auctioned certificates to permit additional development density in key areas targeted for public investment. This is a market-based way to achieve a similar outcome of sharing betterment value with the community. Numerous cities are now experimenting with this approach. 14

\footnotetext{
${ }^{8}$ Archer, R.W., 1976. The Sydney Betterment Levy, 1969-1973: an experiment in functional funding for metropolitan development. Urban Studies, 13(3), pp.339-342. Available at https://www.prosper.org.au/wp-content/uploads/2019/07/Urban-Stud-1976-Archer-339-42.pdf

9 See EPSDD Annual Reports available at https://www.planning.act.gov.au/ data/assets/pdf file/0016/1430440/2018-19-EPSDD-AnnualReport.pdf and https://www.planning.act.gov.au/ data/assets/pdf file/0008/1676942/2019-20EPSDD-Annual-Report.pdf

10 These are published in the Disallowable Instrument (DI2017-208) Planning and Development (Lease Variation Charges) Determination 2017 (No 2) https://www.legislation.act.gov.au/di/2017208/default.asp

11 Nicholls, D. and S. Anthony. 2010. Final Report on the Review of the Change of Use Charges System in the ACT. Available at http://www.treasury.act.gov.au/Change $\% 20$ of $\% 20$ se $\% 20$ Charge/CUC $\% 20$ \%20Macroeconomics \%20Nicholls \%20report.pdf
}

12 See Suburban Land Agency. 2020. 2019-20 Annual Report. ACT Government. Available at https://suburbanland.act.gov.au/uploads/ckfinder/files/pdf/1 About/Publications and Reports/An nual Reports/Suburban\%20Land\%20Agency\%20Annual\%20Report\%202019-20.pdf

13 The Netherlands is famous for the active role municipalities play in land development in this way. See for example, Needham, B. 1997, Land Policy in the Netherlands. Tijdschrift voor economische en sociale geografie, 88: 291-296. https://doi.org/10.1111/i.1467-9663.1997.tb01606.x

${ }^{14}$ See Mahendra, A., King, R., Gray, E., Hart, M., Azeredo, L., Betti, L., Prakash, S., Deb, A., Ashebir, E. and Ibrahim, A. 2020. Urban Land Value Capture in São Paulo, Addis Ababa, and Hyderabad: Differing Interpretations, Equity Impacts, and Enabling Conditions. Lincoln Institute of Land Policy. Available at https://www.wri.org/research/urban-land-value-capture-sao-paulo-addis-ababa-andhyderabad-differing-interpretations 
One of the main lessons from previous experiences with rezoning betterment taxes is that they affect a politically powerful group of property owners who have positioned themselves for future speculative rezoning gains. The Sydney experience in the 1970s was short-lived only because of this political pressure.

"...the reason for the abolition of the levy was partly political advantage." 15

It would be fair to conclude therefore that a tax on rezoning windfalls is uncommon not because it is a bad tax, but because it is a good tax. However, it requires the political will to ensure it persists through the inevitable backlash to become a sustainable part of the tax system. Part of that backlash involves property owners delaying investment in the hope that the tax will be repealed. The possibility of repeal increases the value of developing later, when there is possibly no tax, compared to today, with a tax. This is a real unavoidable implementation effect. However, governments can take a more active role by directly developing housing and other buildings to offset these private sector delays upon implementation.

Like the 1960s, pressure is rising to regain a public share of the value of government-granted development rights. The lessons from previous efforts are that there are many ways to gain this value, of which a well-designed rezoning windfall tax is one. The "public purchase, rezone and develop" is another approach, with the advantage that it avoids inevitable behavioural responses from private property owners due to the political uncertainty inherent in a new rezoning betterment tax. The use of auctioned development permits can also work well in welldefined areas targeted for development. The choice of method is ultimately a political one, but any approach is better than allowing betterment from rezoning to accrue to private property owners.

\footnotetext{
15 See Archer. R.W. 1976. p341.
} 